\title{
Implementation of life cycle costing for a commercial building: case of a residential apartment at Yogyakarta
}

\author{
Peter F Kaming ${ }^{1}$ \\ ${ }^{1}$ Department of Civil Engineering, Universitas Atma Jaya Yogyakarta, Indonesia.
}

\begin{abstract}
Analysis of a design process is very important in controlling the initial costs and future costs in possession of an investment project such as commercial building. Therefore, it should be wise to perform a life cycle cost analysis to determine the cost of any category contained in future cost of the building. The analysis also provide information to see how much the total cost incurred by a development project from initial to the future cost by implementing BS ISO 15686 part 5: 2008, regarding life cycle costing. The purpose of this study is to identify the cost proportion and make long-term plans of a commercial building in term of its life cycle costing from a case of a residential apartment in Yogyakarta, Indonesia. Results of the study show that there are three groups that make up the life cycle cost: the cost of development of the building, the operating costs, and the cost of maintenance and replacement. For a longterm plan the life cycle cost for 25 years the percentage obtained as follows, initial development cost of $42 \%$, operational costs $39 \%$, maintenance and replacement costs $19 \%$. The results would also make comparison with other existing commercial buildings.
\end{abstract}

Keywords: Life cycle costing; service life; residential apartment; BS ISO 15686-5:2008; Yogyakarta

\section{Introduction}

In most developing countries, the government has attempted to develop in all aspects of economy, social, politics and technology to support their programs. For running the programs, the countries need infrastructure and buildings as to facilitate all the program. When developing new building and infrastructure, they mostly did not consider the operating and maintenance of the facilities, this was due to lack of knowledge of life cycle costing (LCC) and encountered with limited funds.

Lack of operation and maintenance strategies to maintain building system performance leads to increased operating and maintenance cost and less healthy buildings. The first step toward improved practices that take advantage of potential operating savings is to identify the O\&M practices routinely performed in buildings. Understanding LCC and service life 
of building component has two major benefits. First, baseline for service life is the benchmark from which to estimate cost for O\&M practices. And second, service life baseline practices can be used as a guide to direct the long terms O\& M cost estimate for the assets.

Indonesia as a developing country in the world today is promoting development in all fields. In implementing directed development, planned, integrated and construction strategy, it is expected construction to be able to deliver efficient and effective results and environmentally accepted. This refers to the constructions sustainable concept, where a development can work together between the concept of responsible development, has the spirit of maintenance, and accountability.

Integrated development has been regulated Building Acts No. 28/2002 [1], Water Resources Acts 74/2002 [2], Highway Acts 38/2004 [3] on the road construction, and Spatial Planning Acts No.26 / 2007 [4], which aims at balancing between buildings and its environment, as well as be a legal umbrella in harmonizing the utilization of space. Once, a top Public Utility Officer explained that "the future of development policy should be able to boost the quality of the environment, no exception public works infrastructure must meet the characteristics of balance and equality, holds a long-term and systematically saving". The policy the development of which was to apply the concept of construction sustainable, maintain and promote an increase in the percentage of green space against other cultivated areas, maintaining conservation areas, especially urban region, as well as realizing eco-city improve supervision in the aspect of environment control construction implementation.

In line with the concept of sustainable constructions, costs incurred in the development process is based on the calculation of life cycle cost, which is an integrated process in decision making, planning and control, procurement, operational, security, and the final value assets, see Barringer and Weber [5].

The purpose of the life cycle cost is to manage the process repeated from the planning to the destruction or replacement of assets, to manage the lifecycle cost (long-term) of the short-term savings, to ensure the appropriate consistent quality service of the designed building, to improve sustainability and lowers the risk of failure and maximize the potential and advantages of the provision of services, in order to minimize the associated costs throughout the life of the building itself, see Langdon [6].

Analysis of the life cycle cost of a design process that is important in controlling the cost of initial and future costs in possession of an investment project. Therefore, it is necessary to do a life cycle cost analysis study to determine the cost of any category contained in university building construction project in the university, and also see how much the total costs incurred by a project development a building ranging from the design phase to the technical life of the building.

In planning life cycle cost, information of the service life of component used such as equipment, and building materials are needed. This is something interesting because whenever service life assessment is only done on a building in overall activities. Determine the service life calculation aims at facilitating the maintenance and replacement of components of the building materials that have overdue the limit of its service life.

The objectives of the study were: 1). to identify service life of component of the material a building; and 2). to provide a long-term plan of 25-year life cycle cost a university building on the Universitas Atma Jaya Yogyakarta.

The building is located in the complex of UAJY Yogyakarta. This development is a tradition separate design and construct project. Contract system used was a lump sum method. This university building plans take as long as 1 year. The building is planned to have 5 floors and functioned for offices, class rooms, auditorium. 


\section{Literature Review}

\subsection{Definition of Life Cycle Costing (LCC)}

There is some understanding of the LCC, according to some experts, including as follows:

1. According Asworth [7], the cost of the life cycle of a building or structure covers total costs associated ranging from stage the beginning until the end of the demolition phase.

2. According to Barringer and Weber [5], LCC is a modeling concepts cost calculation of its early to demolition of an asset of a project as a tool to take a decision on a study analysis and calculation of the total existing costs during its life cycle.

3. According Pujawan [8], the cost of the life cycle (Life Cycle Cost) of aitem is the sum of all expenses relating to the item since designed to unused. In other words, the cost of the building is the cost over the life of the plan building. Therefore, Life Cycle Cost can be formulated as follows:

LCC $=$ Initial Cost + Cost + Cost of Care and Use of replacement wherein, the initial cost is the cost of the planning and execution of the building, the cost of usage is the cost incurred during the building operations, and maintenance and replacement costs are costs for maintenance and replacement the constituent components of the building during the design life of the building.

The main usefulness of Life Cycle Cost is at the time of the evaluation of alternative solutions to certain design problems, for example, an option may be available for the roof of a new project. It is necessary to review not only the initial cost, but also the cost of maintenance and repair, service life plan, appearance, and things that might affect the value as a result from the available options. Although aspects of appearance is a consideration aesthetics, and so it is subjective, but it cannot be ignored in the overall evaluation of these alternatives. Thus, Life Cycle Cost is a combination of calculation and wisdom.

Application Life Cycle Cost for major projects in the industry construction causes utilization of buildings and structures form can really different. However, a problem arises in practice because although the initial construction costs are relatively clear and unexpected at the design stage not so for the usage fee. It required calculation thorough review of the costs incurred from construction to the demolition of the building.

\subsection{Life Cycle Cost Plan}

Life Cycle Cost Plan is a plan for spending the proposal of a construction project over the life of the project. On execution of development, ranging from ideas, feasibility studies, planning, implementation, to maintenance and dismantling operations require miscellaneous costs, which are grouped into several components, namely: 1) Cost of construction: a) direct costs; b) indirect costs. 2). Operational costs: a) cleaning costs; b) The cost of utilities; c) cost of administration. 3). The cost of maintenance and replacement. 4). The final value of the building.

\subsection{LCC Previous Studies}

The following were reviews of previous studies regarding LCC that mostly carried by Indonesia researchers and mostly in the context building projects.

\subsubsection{LCC for Teluk Bayur Port [9]}

Title of research compiled by alzahri is the application of life cycle costs the construction of the pier (pier case studies CPO Teluk Bayur Port). This Research aimed at identifying factors, and variable life cycle cost in planning the development of the construction dock crude palm oil (CPO) on Teluk Bayur port fields, and determine the amount of the life cycle cost. The methodology used in this study is, first conduct a study literature, both perform model selection using a variable life cycle cost Izzati method, the 
third conduct field surveys, the fourth calculating life cycle cost, fifth conclusion. The conclusion of this study were: 1) Conceptual Model was selected Izzati model life cycle costing. Variables used in the planning model CPO pier construction that acquisition costs, operating costs and maintenance, and residual value. 2) The total life cycle cost CPO dock bay Bayur is Rp. 163,196,675,124. 3) In the 9th year have experienced payback period. 4) The application of life cycle cost for construction of the pier CPO Gulf Bayur in the year to 30, earned a profit of Rp. 48,640,121,124.

\subsubsection{LCC Mixed Office \& Residential Building at Manado [10]}

Title of research compiled by Grace Priscilla Kamagi is Analysis life cycle cost of the building (case study: building projects Rukan (Mixed Office and Residential) Bahu Mall Manado. In this study the LCC was applied for 20 years. The methods used is the conduct literature and field studies. The second method used was mutual support to achieve the ultimate goal of research. It also made use of the Internet to search for information relating with research. This study used a life cycle analysis of the actual cost, namely life cycle cost calculation is based on building materials as per specifications cost planning of 9 buildings Rukan Block-N Bahu Mall Manado. To facilitate calculation then there were some cost data needed to be benchmarked. Data cost were: budget planning (RAB) and the list of unit prices of materials and wages. Analysis jobs were reviewed for the work of walls, floors and roofs. The conclusion of this study were: 1) By using the basic calculation of the project life cycle cost of development of Rukan Bahu Mall Manado, for work items walls, floors, and roofs, it was obtained a total cost $=R p 1,722,634,337$. 2) Based on the calculation of the life cycle cost of the construction project Rukan Bahu Mall Manado, for work items, walls, floors, and roof, then the result is the breakdown as follows: cost of capital construction (beginning) of Rp.574.598.000 (33.36\%), cost for maintenance of the wall of Rp. 722,742,750 (41.96\%), cost for floor maintenance Rp. 1,059,551 (0.06\%), cost for roof maintenance Rp. 418,818,353 (24.31\%), and costs of dismantling Rp. 5,415,681 $(0.31 \%)$.

\subsubsection{LCC Campus Center Building Institute Building (ITB) [11]}

Title of research conducted Kawtharazlanshah Koento namely "Estimates life cycle cost (initiation of the concept of green building) campus center ITB". Life-cycle cost calculations performed included some aspects of cost: initial cost, the cost of electricity, clean water costs, maintenance costs, costs maintenance, demolition costs, and resale value. Calculations were performed taking into account the choices made after the service life of the building exhausted. Building service life was assumed to be up to 30 years. The first option was destroyed building after passing the maid, and therefore costs demolition taken into account in the calculation of life-cycle cost. The second option was the building was sold after passing the maid, so the calculation of life-cycle taking into account the cost resale value ITB Campus Center Building. The conclusion of this research was, most cost aspects the calculation of life-cycle cost was the initial cost of building Campus Center ITB which reached Rp. 16,627,638,200. The cost reached $83.93 \%$ of the overall total life-cycle cost at the first option and $80.31 \%$ in the second option. For an annual cost incurred, costs of maintenance was an aspect that had the largest percentage, reaching Rp.2.536.221.568. The cost reached $12.8 \%$ of the total life-cycle cost at the first option and $12.25 \%$ in the second option.

\subsubsection{LCC Diamond Building at Malaysia [12]}

Based on the analysis conduct by Firsani and Utomo (2012) the study with the titled "Life Cycle Cost Analysis on Diamond Building Green at Malaysia "could be concluded as follows: 1) Cost category contained on Diamond Project Building, namely the Initial Cost, 
Energy Cost, Operational and Maintenance Cost, and Replacement Cost. 2) Using the Present Worth Method on the level of interest rate (i) $=6 \%$ and the period of analysis (n) = 10 years. Total cost of living (Life Cycle Cost) from Diamond Building Malaysia were: Rp. 759.290.649.000, with the details as follows: a) Initial Cost of Rp 572.000.000.000, Energy Cost Rp. 5.599.000.000, Operational and Maintenance Rp 182.000.000.000, and Replacement Cost of Rp.201.000.000. b) In a sensitivity analysis performed on large Life Cycle Cost value of the rate changes, and interest rates range $\pm 30 \%$, it can be seen that changes in interest rates are not sensitive to change Life Cycle Cost. c) At LCC modeling, it can be seen that the percentage each cost category against the total cost if no taking into account the residual value, i.e. Initial Cost of $75.306 \%$, amounting to $0.737 \%$ Energy Cost, Operational and Maintenance Cost of $23.932 \%$, and Replacement Cost of $0.026 \%$, while if taking into account the residual value, the percentage of each transformed into cost categories, namely Initial Cost were 62.44\%, 0.61\% Energy Cost, Operational and Maintenance Cost of $19.84 \%$, Replacement Cost of $0.02 \%$, and Residual Cost was $17.09 \%$. Modelling of LCC could also ben note that with or without taking into account the residual value, the largest percentage of the LCC on Diamond Building Project was the initial cost.

\subsubsection{LCC Hostel Building at Kediri, Eastern Jawa, Indonesia [13]}

The study regarding LCC had carried out in Kediri at a hostel building with the following components: 1) There were three groups of estimation of LCC for the hostel building, namely development cost Rp. 4.290.000.000 (46\%), operational cost 2.360.412.125 (26\%), and maintenance and replacement cost Rp.2.179.307.000 (28\%). 2) In operational, the biggest cost go to administration Rp.56.000.000 (61\%), followed by utility Rp.22.116.485 (22\%), and cleaning Rp.16.300.000 (17\%). 3) For maintenance and replacement, the biggest was ME Rp.987.685.000 (38\%), sanitary Rp.625.000.000 (24\%), wall Rp.431.328.000 (16\%), ceiling Rp.197.500.000 (7,6\%), accessory Rp.83.500.000 (3,3\%), floor Rp.202.947.000 (7,8)\% and roof Rp.62.940.000 (2,7\%).

\subsubsection{LCC for a University Building [14]}

The purpose of this study is to identify the cost proportion and make long-term plans of a university building in term of life cycle costing in the area of Univeristy of Atma Jaya Yogyakarta (UAJY). Results of the study show that there are three groups that make up the life cycle cost: the cost of development of the building, the operating costs, and the cost of maintenance and replacement. For a long-term plan the life cycle cost for 25 years the percentage obtained as follows, initial development cost of Rp. 10,301,450,000 (43\%), operational costs Rp. 11,085,000,000 (46\%), maintenance and replacement costs Rp. 2.660.570.080 (11\%).

\section{Research Method}

\subsection{Data Collection and Analysis}

Data collection methods used in this study includes following stages. 1) Preparation: stages of preparation is done is to formulate the research problem, research objectives, and explore data to the consultant's office to run smoothly. 2) Collect data: steps taken in this phase are: a). The field survey to see if there are projects eligible to be used as a research location and conduct the permitting process to the performer, or the owner of the project. b). send questionnaires to the respondents, to collect data for supporting the research. 3) Data Analysis: after the data collected lifecycle cost calculation using MS-Excel. 4) Discussion: step taken is to discuss the results of a study of life cycle cost calculation results for the conclusion. 5) Conclusions and Recommendations: steps being taken is to give conclusions and suggestions on the results obtained in this study. 


\subsection{The Building Under Studied}

The apartment building is situated at Babarsari region, in Yogyakarta. The building consists of 8 floors, 203 units with a total of floor area of $16,719 \mathrm{~m} 2$. It was built in the land of 4000 $\mathrm{m} 2$ in the year of 2013, but the building cost was recalculated using cost data of 2016. It was then estimated life cycle cost of 25 years using history data obtained from the office for building maintenance of the apartment.

\subsection{Cost Model for LCC}

The model estimate was adopted the example from ISO 15686 part 5 for LCC [15].

\subsubsection{Construction Cost.}

All costs of initial construction work on the building: 1) Building Works Costs. Cost of building works and external works (Presented in the SFCA element cost structure); 2) Other Construction Related Costs. All costs payable by the client in connection with the building or constructed asset.

\subsubsection{Maintenance Costs}

All costs of replacement, maintenance, repair and adaptation of the constructed asset (Presented in the SFCA element cost structure. They consists of 1) Major Replacement Costs. It includes scheduled replacement and major components. This will form the detailed asset life cycle replacement program. 2) Minor Replacement and Repairs Costs. Scheduled replacement of parts and scheduled maintenance and repairs to components and associated making good and minor redecorations including planned preventative maintenance. 3) Unscheduled Replacement, Repairs and Maintenance Costs. Allowance for unforeseen maintenance arising from early failure, inappropriate use etc. 4) Redecorations Scheduled redecorations..5) Refurbishment and Adaptation Costs Scheduled refurbishment and adaptation during the period of analysis. Exclude refurbishment and adaptation carried out as part of the initial construction, which should be included under the construction costs.

\subsubsection{Operation Costs}

All costs of operating the building or facility arising from the building itself rather than from its occupancy, excluding maintenance costs. It includes periodic: routine and specialist cleaning; windows and external surfaces cleaning windows, curtain walling, glazed screens, cladding, sun screening etc.; internal cleaning; and external works cleaning. Part of the operation cost is fuel consumption. Fuel Show cost of different fuel separately e.g. 1) Gas, 2) Electricity. 3) Fuel oil. 4) Solid fuel (define). 5) Other Include any income from the sale of energy.

\subsubsection{Administrative Costs}

User support costs related to the operation of the building or facility. Property Management All costs involved in managing the operation and maintenance of the building. Includes: 1) Supervisory staff e.g. building supervisor, maintenance manager, facilities manager etc. 2) Professional staff e.g. architects, engineers, surveyors etc. 3) Clerical staff and administrative staff. 4) General and regulatory surveys commissioned by or on behalf of the client

\section{Result of Analysis and Discussion}

\subsection{Data Analysis}

Distributing questionnaires were conducted to determine service life of components of building materials used in the construction of the university building. From 15 people who responded to the questionnaire obtained an average service life and testimony of building 
materials used in the construction of buildings. Table 1 below will explain the average service life and testimony of building materials.

Table 1 Service life for Material Components, Source: Kaming \& Mardiansyah, [13] and other primier data.

\begin{tabular}{|c|c|c|c|c|}
\hline Cost Group & $\begin{array}{l}\text { Component } \\
\text { Material }\end{array}$ & $\begin{array}{l}\text { Service Life } \\
\text { (Year) }\end{array}$ & $\begin{array}{l}\text { Material Brand and } \\
\text { Features }\end{array}$ & $\begin{array}{l}\text { Reference/ } \\
\text { Interview) }\end{array}$ \\
\hline \multirow{3}{*}{ ME } & & 30 & Sony/Samsung/Krisbow & supplier \\
\hline & Water Heater & 15 & Ariston/Paloma/Rinnai & supplier \\
\hline & $\mathrm{AC}$ & 15 & LG/Panasonic/Sharp & consultant \\
\hline \multirow{3}{*}{$\begin{array}{l}\text { Roof } \\
\text { Structure }\end{array}$} & Steel roof frame & 30 & Prima Truss & supplier \\
\hline & Roof clay tile & 20 & Sokka/Mutiara/KIA & consultant \\
\hline & Gutter & 15 & Steel/Zinc & consultant \\
\hline \multirow[t]{9}{*}{ Wall } & Wall paint & 8 & Taka/Dulux/Movilex/Nippon & supplier \\
\hline & Aluminium paint & 12 & Taka/Dulux/Movilex/Nippon & supplier \\
\hline & Wood paint & 15 & Taka/Dulux/Movilex/Nippon & supplier \\
\hline & Frame aluminium & 15 & Lokal/Aluplus/Alurre & consultant \\
\hline & Door aluminium & 15 & Lokal/Aluplus/Alurre & consultant \\
\hline & Timber frame & 30 & Jati/Merbau/Bengkirai & consultant \\
\hline & Timber door & 30 & Jati/Merbau/Bengkirai & consultant \\
\hline & Timber windor & 30 & Jati/Merbau/Bengkirai & consultant \\
\hline & $\begin{array}{l}\text { Door and window } \\
\text { glass }\end{array}$ & 20 & Glass $3 \mathrm{~mm}$ & consultant \\
\hline \multirow[t]{2}{*}{ Floor } & Granit & 20 & Roman/Platinum & supplier \\
\hline & Ceramic & 20 & Asia Tile/ Roman/Platinum & supplier \\
\hline \multirow[t]{2}{*}{ Ceilimg } & Gypsum & 15 & Local & consultant \\
\hline & GRC & 18 & KalsiBoard & consultant \\
\hline \multirow[t]{7}{*}{ Sanitary } & Wastafel & 8 & Toto/America Standard & consultant \\
\hline & $\begin{array}{l}\text { Stainless steel } \\
\text { sink }\end{array}$ & 12 & Enchanting & consultant \\
\hline & Water crane & 3 & Enchanting & consultant \\
\hline & Water closet & 15 & Toto/America Standard & consultant \\
\hline & Shower & 8 & Enchanting & consultant \\
\hline & Floor drain & 8 & Enchanting & consultant \\
\hline & PVC pipe & 30 & Waving & consultant \\
\hline \multirow[t]{3}{*}{ Accessory } & $\begin{array}{l}\text { Slot door \& } \\
\text { window }\end{array}$ & 10 & Solid /Paloma/Dorma & supplier \\
\hline & $\begin{array}{l}\text { Handle door \& } \\
\text { window }\end{array}$ & 10 & Solid /Paloma/Dorma & supplier \\
\hline & $\begin{array}{l}\text { Hinge door and } \\
\text { window }\end{array}$ & 20 & Solid /Paloma/Dorma & supplier \\
\hline \multirow[t]{9}{*}{ ME } & Lamp standard & 5 & Philips/Krisbow/GE/Osram & supplier \\
\hline & Lamp down light & 5 & Philips/Krisbow/GE/Osram & supplier \\
\hline & Wall Stop contact & 20 & Broco/Jung/Panasonic & consultant \\
\hline & Saclar single & 20 & Broco/Jung/Panasonic & consultant \\
\hline & Sacla multiple & 20 & Broco/Jung/Panasonic & consultant \\
\hline & Fitting & 20 & Broco/Jung/Panasonic & consultant \\
\hline & Lift & 30 & Hyundai/Otis/Schneider & consultant \\
\hline & Fire alarm & 30 & Siemens & supplier \\
\hline & Telephon & 15 & Telkom/Panasonic/Samsung & consultant \\
\hline
\end{tabular}


The initial cost comprised of: preparation, excavation, concrete, reinforcement, bore piles, etc .In the study, the initial construction cost was calculated using 2015 cost data. The total initial cost was estimated Rp.104.421.000.000. with the floor area of $13.331 \mathrm{~m} 2$, the unit cost was over Rp.7.833.000 /m2.

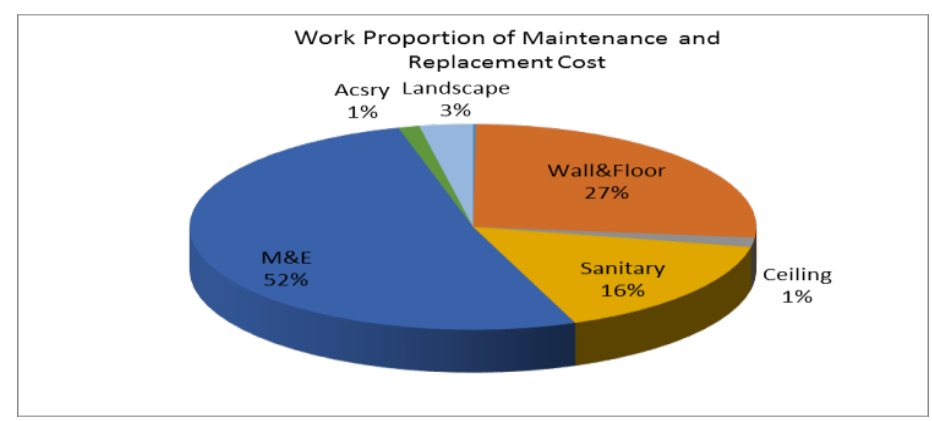

Fig. 1. Proportional of Estimated Maintenance \& Replacement Cost over 25 years.

\subsection{Maintenance and Replacement over 25 Years.}

Maintenance and replacement cost were calculated based on period of service maintenance and service life data obtained from Table 1. Total maintenance cost was about Rp. 47.540.000.000 over 25 years. The biggest proportion went to component of the cost of electrical and mechanical equipment and devices (51.62\%); floor and wall maintenance including repainting was $26.5 \%$; and sanitary work was almost $16 \%$, the rest was for others. See Figure1.

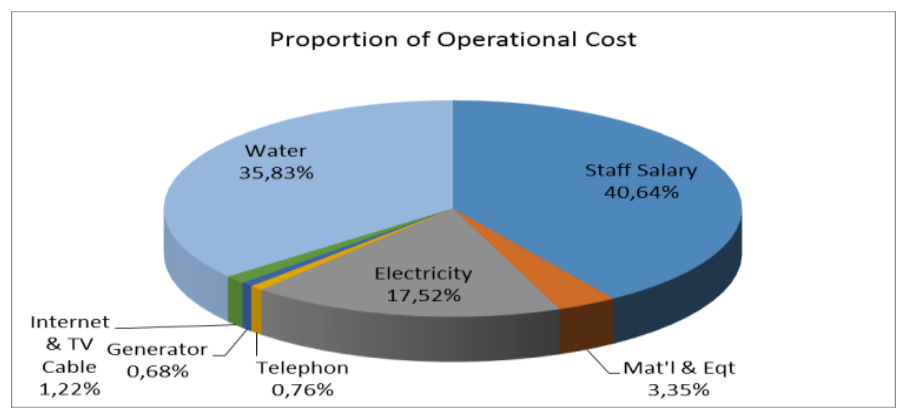

Fig. 2. Propotional of Estimated Operational Cost of the Building over 25 years. 


\subsection{Operating Cost over 25 Years}

The operational cost was estimated with a total of Rp. 98.545 .000 .000 over 25 years with a biggest proportion went to administration cost of $40.64 \%$, water $35.83 \%$, electrical $17.52 \%$, the rest was for other. See Figure 2.

\subsection{Proportional LCC for the Apartment.}

The proportional of overall construction cost, operational cost and maintenance and replacement cost were showed in Figure 3. The construction cost was the biggest proportion with $41.68 \%$, followed by operational cost of $39.34 \%$, and the maintenance and replacement cost of $18.89 \%$.

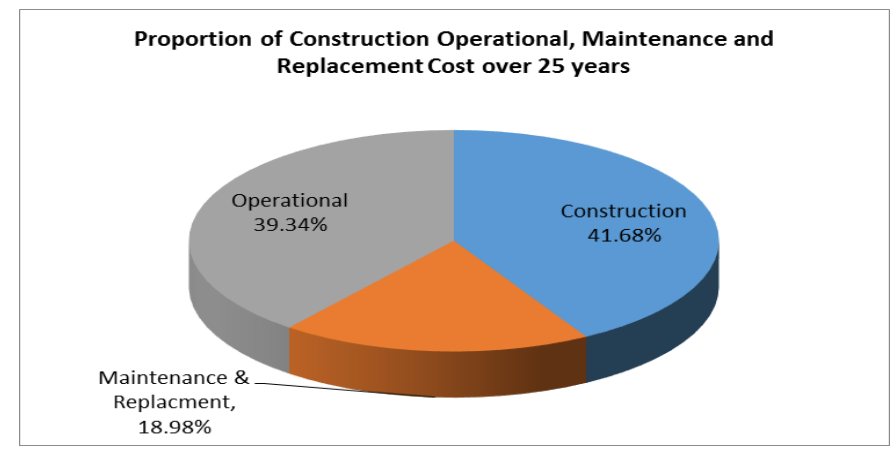

Fig. 3. Proportional of Total Cost of the Building over 25 years.

\subsection{Comparison with Previous Studies}

Since the LCC model of previous studies [9-12] were varied in terms of periods of LCC, and methods, they were difficult to compare. The comparison were made for other previous studies $[13,14]$ because they were applied the same period of 25 years of LCC, and utilized the same method. Table 2 shows the comparison for average proportional of three type of building with the initial construction cost (43.67\%), operational cost $(37.00 \%)$, and maintenance and replacement costs (19.33\%).

Table 2. Comparison LCC Three Studies.

\begin{tabular}{|l|c|c|c|}
\hline Project & $\begin{array}{l}\text { Initial Construction } \\
\text { Cost (\%) }\end{array}$ & $\begin{array}{l}\text { Operating Cost } \\
\text { (\%) }\end{array}$ & $\begin{array}{l}\text { Maintenance \& } \\
\text { Replacement Cost (\%) }\end{array}$ \\
\hline Hostel [13] & 46 & 26 & 28 \\
\hline University [14] & 43 & 46 & 11 \\
\hline Apartment * & 42 & 39 & 19 \\
\hline Average & 43.67 & 37.00 & 19.33 \\
\hline
\end{tabular}

*This study.

\section{Conclusions and Recomendation}

The study regarding LCC has been carried out in Yogyakarta at a university building with the following cost components. 1) There were three groups of estimation of LCC for the university building, namely development cost Rp. 104.421.000.000 (41.68), operational cost Rp.98.545.000.000 (39.84\%), and maintenance and replacement cost Rp. 47.540 .000 .000 (18.98\%). 2) On maintenance and replacement cost, the biggest proportion went to maintenance and replacement of a) electrical and mechanical divices $(52 \%)$, b) 
floor and wall ceramic tile of almost $27 \%$; followed by c) sanitary replacement of $16 \%$; the rest was for other works. 3). On operational, the biggest cost went to administration cost of $40.64 \%$, water cost of $35.83 \%$, electricity cost of $17.52 \%$, and the rest for other expenses.

This study provided the following recommendation. The service life used in this study was been gathered from stakeholder involved in the suppliers, consultants, and academics, involved in the construction industry, as well as the maintenance officers from the university had some drawbacks in term of its quality and quantity. Perhaps the similar information should be gathered for accurate based the empirical research methodology.

The cost items used in this study was subjective and mostly be relied on the experience of the individual professional and available of service life of the components. The cost could also be adjusted when it could be reduced based on the limited resource available. In future, it was recommendated method of the Davis Langdon and ISO 15686 part 5 be applied in whole life cycle costing (WLCC) [16]. Future research should be emphasize at service life for building and infrastructure components for local condition adopting factor methods of ISO 15686 part 1, and create specific WLCC research model for more type of building and civil engineering projects in developing country such as Indonesia.

\section{Acknowledgement}

This research is internally funded by Universitas Atma Jaya Yogyakarta (UAJY). The author was grateful to the Research and Service Boards of UAJY, building officers, supplier, consultant who participated in this study. The author also thankful to reviewers for their commend and critics for improvement the quality of the paper.

\section{References}

[1] National Acts of Indonesia, number 28 year of 2002 regarding Building Development (2002).

[2] National Acts of Indonesia, number 74 year of 2002 regarding Water Resource (2002).

[3] National Acts of Indonesia, number 38 year of 2004 regarding Highway Development (2004).

[4] National Acts of Indonesia, number 26 year of 2007 regarding Spatial (2007).

[5] P. H Barringer, \& D.Weber. "Life Cycle Cost Tutorial", Fifth International Conference on Process Plant Reliability and Hydrocarbon Processing, Gulf Publishing Company., Texas. (1996).

[6] D. Langdon. Life Cycle Cost (LCC) as a construction to sustainable construction: a common methodology, Darvis Langdon Management Consulting (2007).

[7] A. Asworth. Cost Planning for Building (in Bahasa), PT. Gramedia Pustaka Utama, Jakarta. (1994).

[8] I.N Pujawan, Engineering Economics, (in Bahasa) Guna Widya, Surabaya. (2004).

[9] Alzahri. Implementation of Life Cycle Cost in Developing a Dock: Case of the Dock for CPO at Teluk Bayur Padang. (in Bahasa) (2013).

[10] G.P Kamagi. Analysis of Life Cycle Cost for a Building: case of mixed office and residential building of Bahu Mall, at Manado (in Bahasa). Jurnal Sipil Statik, 1(8) 549-556. (2013).

[11] K.A Koento, Estimating Life Cycle Cost: Initial development of the concept for green building development for Campus Center ITB. (in Bahasa). (2012).

[12] I. Firsani, \& C. Utomo. Analisis LCC pada Green Building Diamond Building Malaysia, Jurnal Teknik ITS Vol 1(34-39). (2012).

[13] P.F Kaming.\& J. Mardiansyah, Implementation of Life Cycle Costing: A Case of Hostel Building in Kediri, Eastern Jawa, Indonesia, Proceeding ICRMCE, Surakarta, UNS. (2015).

[14] P.F Kaming Implementation of Life Cycle Costing for a University Building, Indonesian Journal of Life Cycle Assessment and Sustainability, Vol.1 (1). (2016).

[15] BSI. BS ISO 15686-1:2008 Building and Construction Assets - Service Life Planning - Part 1: Service Life Methodology, BSI-BCIS. (2008).

[16] BSI. BS ISO 15686-5:2008 Building and Construction Assets - Service Life Planning - Part 5: Life Cycle Costing, BSI-BCIS. (2008). 